\title{
Development of a radioimmunoassay for measuring gonadotrophin releasing hormone in patients receiving treatment
}

V A MOBSBY, M L KNAPP, R S FINK, * V M OSGOOD, $\dagger$ P D MAYNE The Departments of Chemical Pathology, Charing Cross and Westminster Medical School, Westminster Hospital, and *West Middlesex University Hospital, Isleworth, Middlesex, and the †Department of Endocrinology, Royal Free Hospital and Medical School, London

SUMMARY A radioimmunoassay for the measurement of gonadotrophin releasing hormone $(\mathrm{GnRH})$ in plasma and urine using readily available reagents was developed. The GnRH assay showed good precision, recovery, and parallelism over a wide range of GnRH concentrations with a sensitivity of $15 \mathrm{pg} / \mathrm{ml}$. The assay was compared with a commercially available kit (Buhlmann Laboratories). Although the Buhlmann kit showed acceptable precision, recovery, sensitivity, and correlation with the developed $\mathrm{GnRH}$ assay for plasma samples, lack of parallelism of serially diluted plasma and urine samples was consistently observed, together with a poor correlation with the developed GnRH assay for urine, suggesting a matrix effect with the Buhlmann kit.

The developed assay is suitable for measuring GnRH in samples obtained from patients receiving pulsatile infusions of $\mathrm{GnRH}$. In contrast, the commercially available Buhlmann kit was unsuitable for measuring plasma $\mathrm{GnRH}$ as the kit had a top standard of only $160 \mathrm{pg} / \mathrm{ml}$, well below the peak plasma concentration. It would not be possible to dilute samples for analysis because of the lack of parallelism of diluted samples compared with standards obtained with the Buhlmann assay.

Gonadotrophin releasing hormone $(\mathrm{GnRH})$ is secreted by the hypothalamus in pulses and stimulates the synthesis and release of luteinising hormone and follicle stimulating hormone from the anterior pituitary gland.' The biological activity of GnRH depends on the pulse amplitude and frequency, changes in which change the relative proportion of luteinising hormone to follicle stimulating hormone secretion. $^{2}$

Pulsatile administration of synthetic GnRH, which mimics the early follicular phase secretory pattern, has been used to induce ovulation in women with hypothalamic hypogonadism ${ }^{3}$ and in the management of polycystic ovarian syndrome. ${ }^{4}$ It has also been used successfully in the management of delayed puberty and with some success in men with hypospermia. Successful treatment of some of these disorders has become possible through the advent of the microcomputerised, programmable infusion pump which stimulates the physiological pattern of $\mathrm{GnRH}$ release. In such patients there is a requirement to assess pump function and to evaluate patients with a suboptimal response of gonadotrophin release. Faster pulse frequencies reduce the plasma concentrations of both gonadotrophins. Long term administration of GnRH analogues, causing down-regulation of hormone secretion, is being assessed in the management of hormone sensitive disorders such as endometriosis ${ }^{5}$ and prostatic carcinoma. ${ }^{6}$

Although several workers have developed radioimmunoassays for $\mathrm{GnRH}$ in plasma and urine, ${ }^{7-10}$ there are few commercially available assays and no published comparisons of assay performance.

We describe the development of a radioimmunoassay to measure $\mathrm{GnRH}$ in plasma and urine using readily available reagents as part of a study in the use of pulsatile GnRH in the management of female infertility.

\section{Material and methods}

All reagents were analytical grade.

Phosphate buffer $(0.05 \mathrm{~mol} / \mathrm{l}, \mathrm{pH} 7.4)$ containing $0.5 \% \mathrm{w} / \mathrm{v}$ bovine serum albumin (BSA) was used as 
assay buffer. Sodium azide $(0 \cdot 1 \% \mathrm{w} / \mathrm{v})$ was added as a preservative.

Sheep anti-GnRH antiserum (No 94) was kindly donated by Dr HM Fraser, MRC Reproductive Biology Unit, Edinburgh, Scotland. The immunological activity of the antiserum was directed against the carboxyl end of the molecule and reacted equally with the 1 to 4-10 GnRH peptides. " Cross reaction with other GnRH fragments and related peptides was negligible. The antiserum was suppled as a 1/10 dilution and stored in $5 \mu \mathrm{l}$ aliquots at $-20^{\circ} \mathrm{C}$.

(3-[ $\left.{ }^{125} \mathrm{I}\right]$ iodotyrosyl) $\mathrm{GnRH}$ with a specific activity of $78 \times 10^{6} \mathrm{kBq} / \mu \mathrm{mol}$ was supplied by Amersham International. The tracer was reconstituted in assay buffer to give about $30000 \mathrm{cpm}$ per assay tube.

Synthetic GnRH-HRF Ayerst No $1175(0.5 \mathrm{mg})$ was dissolved in $2 \mathrm{ml}$ sterile diluent (Ayerst Laboratories Ltd, Andover, England). This was made up to $1000 \mathrm{ml}$ with distilled water to give a concentration of $0.5 \mu \mathrm{g} / \mathrm{ml}$ and was further diluted to give a stock standard of $1000 \mathrm{pg} / \mathrm{ml}$ which was stored in aliquots at $-20^{\circ} \mathrm{C}$. Before use the stock standard was diluted with assay buffer to give GnRH concentrations of $31 \cdot 25$ to $1000 \mathrm{pg} / \mathrm{ml}$.

Polyethylene glycol 6000 (PEG, 20\% w/v) in assay buffer, together with bovine gamma globulin $(4 \% \mathrm{w} / \mathrm{v})$ as carrier serum, was used to separate the bound from the free fractions.

Blood samples from patients and healthy laboratory volunteers were collected into cooled $10 \mathrm{ml}$ edetic acid tubes containing $0.5 \mathrm{ml}$ Trasylol $(20000$ Kallibrein Inactivator Units/ml, Bayer Germany, Berkshire, England) and immediately centrifuged at $3000 \mathrm{rpm}$ for five minutes. The plasma was stored at $-20^{\circ} \mathrm{C}$ until assay. Random urine samples from similar subjects were frozen immediately and likewise stored at $-20^{\circ} \mathrm{C}$ until assay. Samples were analysed within one week of collection.

Aliquots of GnRH standards, plasma, or urine $(0.25 \mathrm{ml})$ were extracted with absolute ethanol $(1.0 \mathrm{ml})$. The protein precipitate was removed by centrifugation $\left(2500 \times g\right.$ for fifteen minutes at $\left.4^{\circ} \mathrm{C}\right)$ and the supernatant decanted into clean glass tubes and evaporated under a stream of air at $70^{\circ} \mathrm{C}$.

The procedure adopted for the final assay conditions is outlined in table 1.

The extraction procedure and analytical performance of the GnRH assay was evaluated and compared with a commercially available radioimmunoassay (Buhlmann Laboratories Ltd, Basel, Switzerland) which had a reported sensitivity of $2.25 \mathrm{pg} / \mathrm{ml}$ and a top standard of $160 \mathrm{pg} / \mathrm{ml}$. Briefly, for the assay of plasma GnRH by the Buhlmann kit, sample $(1.5 \mathrm{ml})$ was extracted with absolute ethanol $(6.0 \mathrm{ml})$. After vortex mixing and centrifugation at $1000 \times g$ for 20 minutes at $4^{\circ} \mathrm{C}$ the upper ethanolic extract was
Table 1 Procedure for radioimmunoassay of $\mathrm{GnRH}$

\begin{tabular}{|c|c|c|c|c|c|}
\hline & $\begin{array}{l}\text { Total } \\
\text { counts }\end{array}$ & $N S B$ & Bo & Standards & $\begin{array}{l}\text { Controls } \\
\text { and } \\
\text { samples }\end{array}$ \\
\hline $\begin{array}{l}\text { Buffer } \\
\text { GnRH standard }\end{array}$ & & $0 \cdot 1$ & 0.05 & 0.05 & \\
\hline $\begin{array}{l}\text { Control or sample } \\
\text { GnRH anti-serum }\end{array}$ & & & 0.05 & 0.05 & $\begin{array}{l}0.05 \\
0.05\end{array}$ \\
\hline \multicolumn{6}{|c|}{ Vortex mix and incubate at $4^{\circ} \mathrm{C}$ for $5-6$ hours } \\
\hline${ }^{125}$ I GnRH & 0.05 & 0.05 & 0.05 & 0.05 & 0.05 \\
\hline \multicolumn{6}{|c|}{ Vortex mix and incubate at $4^{\circ} \mathrm{C}$ for $18-20$ hours } \\
\hline $\begin{array}{l}\text { Carrier serum } \\
\text { PEG solution }\end{array}$ & & $\begin{array}{l}0.05 \\
0.5\end{array}$ & $\begin{array}{l}0.05 \\
0.5\end{array}$ & $\begin{array}{l}0.05 \\
0.5\end{array}$ & $\begin{array}{l}0.05 \\
0.5\end{array}$ \\
\hline \multicolumn{6}{|c|}{$\begin{array}{l}\text { Vortex mix and incubate at } 4^{\circ} \mathrm{C} \text { for } 15 \text { minutes } \\
\text { Centrifuge at } 2500 \mathrm{~g} \text { at } 4^{\circ} \mathrm{C} \text { for } 15 \text { minutes } \\
\text { Aspirate supernatant } \\
\text { Count for } 300 \text { seconds } \\
\text { Results processed using the WHO Immunoassay Data Processing } \\
\text { Program (PR Edwards, Version A } 5 \text { for Apple II) }\end{array}$} \\
\hline
\end{tabular}

evaporated to dryness and reconstituted in $1.5 \mathrm{ml}$ assay buffer.

Reconstituted extract $(0.5 \mathrm{ml})$ and ${ }^{125} \mathrm{I} \mathrm{GnRH}$ $(0.1 \mathrm{ml}, 10000 \mathrm{cpm}$ per tube) was incubated with rabbit anti GnRH antibody $(0.05 \mathrm{ml})$ for 24 hours at $4^{\circ} \mathrm{C}$. Goat anti-rabbit gammaglobulin $(0.1 \mathrm{ml})$ was then added to separate the free fraction from the bound fraction. After incubation for a further 24 hours at $4^{\circ} \mathrm{C}$ tubes were centrifuged at $1000 \times g$ for 20 minutes at $4^{\circ} \mathrm{C}$. The supernatant was then aspirated and the precipitate counted. Results were processed using the WHO Immunoassay Data Processing Program (PR Edwards, Version A5).

Plasma and urine samples were obtained from healthy laboratory volunteers and from patients receiving pulsatile subcutaneous GnRH injections (Gonadorelin, Ayerst Laboratories Ltd, Andover, England) as treatment for infertility at the department of endocrinology, the Royal Free Hospital, London.

\section{Results}

\section{OPTIMISATION OF ASSAY}

Optimisation of extraction procedure

Bentonite and ethanol have been used to extract GnRH from plasma, ${ }^{9}$ and florisil and ethanol have been used to extract GnRH from urine. ${ }^{10}$ Because the previous studies used acidified methanol, $\mathrm{pH} 2 \cdot 5$, to elute the adsorbed GnRH from bentonite or florisil, the same procedure was used in this study.

Using ethanol extraction, the mean recovery of added $\mathrm{GnRH}(100 \mathrm{pg} / \mathrm{ml})$ from normal male plasma and urine was $113 \%$ and $95 \%$, respectively $(n=2)$. The recovery of extracted GnRH $(100 \mathrm{pg} / \mathrm{ml})$ from normal male plasma and urine using bentonite or florisil adsorption ${ }^{910}$ was only $6 \%$ and $34 \%$, respec- 
tively $(n=2)$. Thus ethanol extraction was used for all subsequent $\mathrm{GnRH}$ assays.

Experiments using normal human plasma and urine spiked with ${ }^{125}$ I GnRH showed that the poor recovery using bentonite and florisil was due to the inability of the acidified methanol to elute GnRH from these adsorbents.

\section{Optimisation of radioimmunoassay}

Experiments were performed in which the incubation time, incubation temperature, first antibody dilution and tracer quantity were varied. The optimal antibody dilution was $1 / 30000$, which gave a Bo of $45 \%$, and the most sensitive (steep) standard curve at low GnRH concentrations. Although tracer quantity was varied from 5000 to $50000 \mathrm{cpm} /$ tube, no significant improvement in sensitivity was noted in reducing the tracer quantity below $30000 \mathrm{pm}$. Table 1 shows the conditions which were found to be optimal with regard to incubation time and temperature, quantities of label, carrier serum, and PEG.

\section{Stability of $\mathrm{GnRH}$ in plasma}

Three blood samples collected in trasylol with GnRH concentrations of 100,250 , and $500 \mathrm{pg} / \mathrm{ml}$ were each split into eight aliquots. For each sample, one aliquot was extracted immediately and another was extracted two and half hours later after standing at room temperature. Both were then analysed. The remaining six aliquots were stored at $-20^{\circ} \mathrm{C}$ and $-70^{\circ} \mathrm{C}$ and then assayed in duplicate after extraction for GnRH at one, two, and four weeks. GnRH immunoreactivity decreased by $20 \%$ at room temperature over a two and a half hour period and after two weeks' storage at $-20^{\circ} \mathrm{C}$ and $-70^{\circ} \mathrm{C}$. Samples stored at $-20^{\circ} \mathrm{C}$ or $-70^{\circ} \mathrm{C}$ for up to one week before extraction showed less than $5 \%$ reduction in GnRH immunoreactivity. Samples were therefore stored at $-20^{\circ} \mathrm{C}$ and extracted and analysed within one week of collection.

\section{EVALUATION OF THE GNRH ASSAY AND BUHLMANN KIT \\ Sensitivity}

The sensitivity of each assay was calculated as two and a half times the standard deviation of $\mathrm{cpm}$ zero standard $(n=20)$. For the GnRH assay the sensitivity was $15 \mathrm{pg} / \mathrm{ml}$ compared with $2 \cdot 1 \mathrm{pg} / \mathrm{ml}$ for the Buhlmann kit.

\section{Recovery}

The recovery of GnRH through the ethanol extraction procedure was evaluated for both assays by adding ${ }^{125} \mathrm{I}$ GnRH to plasma and counting the radioactivity in the final extract. For both assays $77-79 \%$ of the added ${ }^{125} \mathrm{I}$ was recovered. To allow for this incomplete recovery standards were always extracted in an identical manner with that of controls and samples.

The recovery of added GnRH to plasma and urine was assessed by adding $0.05 \mathrm{ml}$ of standard $\mathrm{GnRH}$ to $1.0 \mathrm{ml}$ plasma or urine to give final concentrations of GnRH, ranging from $8-500 \mathrm{pg} / \mathrm{ml}$. The top standard for the $\mathrm{GnRH}$ assay was $1000 \mathrm{pg} / \mathrm{ml}$ so recovery was assessed between $50-500 \mathrm{pg} / \mathrm{ml}$. As the top standard for the Buhlmann Kit was $160 \mathrm{pg} / \mathrm{ml}$, however, recovery was assessed between the lower values of 8 $40 \mathrm{pg} / \mathrm{ml}$. Added GnRH could be recovered quantitatively by either assay with the exception of low concentrations of GnRH in urine using the Buhlmann Kit (table 2).

\section{Precision studies}

For the determination of within assay precision of the GnRH assay, three pools of plasma at different $\mathrm{GnRH}$ concentrations were analysed 20 times in one analytical run. Similarly, three pools of plasma were analysed 20 times to give within assay precision of the Buhlmann kit.

For the determination of between assay precision, three pools of plasma at different GnRH concentrations were analysed in nine consecutive assays. To minimise the effect of the poor stability of GnRH in plasma on the results, the assays were carried out over one week (table 3 ).

\section{Comparison of standards used in the two assays}

Appropriate dilutions of the GnRH standard supplied with the Buhlmann kit were analysed in duplicate, using the GnRH assay. Similarly, appropriate dilutions of the Ayerst Gonadorelin standard used in the GnRH assay were analysed in duplicate using the Buhlmann kit. Both sets of standards gave identical results with either assay.

\section{Parallelism}

Plasma and urine samples, containing high GnRH concentrations, were diluted with assay buffer and compared with the standard curve for parallelism.

Table 2 Mean recovery of GnRH added to a pool of plasma and urine $(n=2)$

\begin{tabular}{|c|c|c|c|c|}
\hline & \multicolumn{2}{|l|}{ GnRH assay } & \multicolumn{2}{|l|}{ Buhlmann kit } \\
\hline & $\begin{array}{l}\text { GnRH added } \\
(\mathrm{pg} / \mathrm{ml})\end{array}$ & $\begin{array}{l}\text { Per cent } \\
\text { recovery }\end{array}$ & $\begin{array}{l}\text { GnRH added } \\
(\mathrm{pg} / \mathrm{ml})\end{array}$ & $\begin{array}{l}\text { Per cent } \\
\text { recovery }\end{array}$ \\
\hline Plasma & $\begin{array}{l}100 \\
250 \\
500\end{array}$ & $\begin{array}{l}99 \\
86 \\
95\end{array}$ & $\begin{array}{r}8 \\
16 \\
40\end{array}$ & $\begin{array}{r}92 \\
107 \\
116\end{array}$ \\
\hline Urine & $\begin{array}{r}50 \\
250 \\
500\end{array}$ & $\begin{array}{r}137 \\
102 \\
89\end{array}$ & $\begin{array}{r}8 \\
16 \\
40\end{array}$ & $\begin{array}{r}56 \\
90 \\
118\end{array}$ \\
\hline
\end{tabular}


Table 3 Within assay and between assay precision

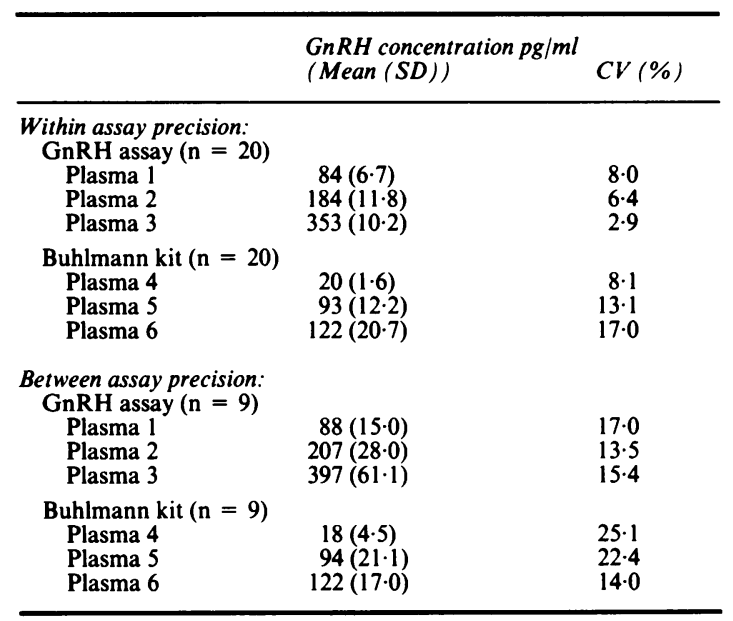

There was a high degree of parallelism using the GnRH assay but not when using the Buhlmann kit (Figs la and b, respectively).

\section{Correlation}

Correlation of the GnRH assay with the Buhlmann kit was assessed by measuring GnRH in plasma and urine samples from healthy laboratory staff and from patients receiving subcutaneous pulsatile GnRH treatment. As parallelism for the Buhlmann kit was poor, it was considered inappropriate to dilute samples with GnRH concentrations above $160 \mathrm{pg} / \mathrm{ml}$.

Results were analysed by least squares linear regression. Deming's correction for slope was not applied because ${ }^{\text {Sex }} / \mathrm{Sx}$ was less than $\mathbf{0 \cdot 2}$, where Sex represents the standard deviation of a single measurement of

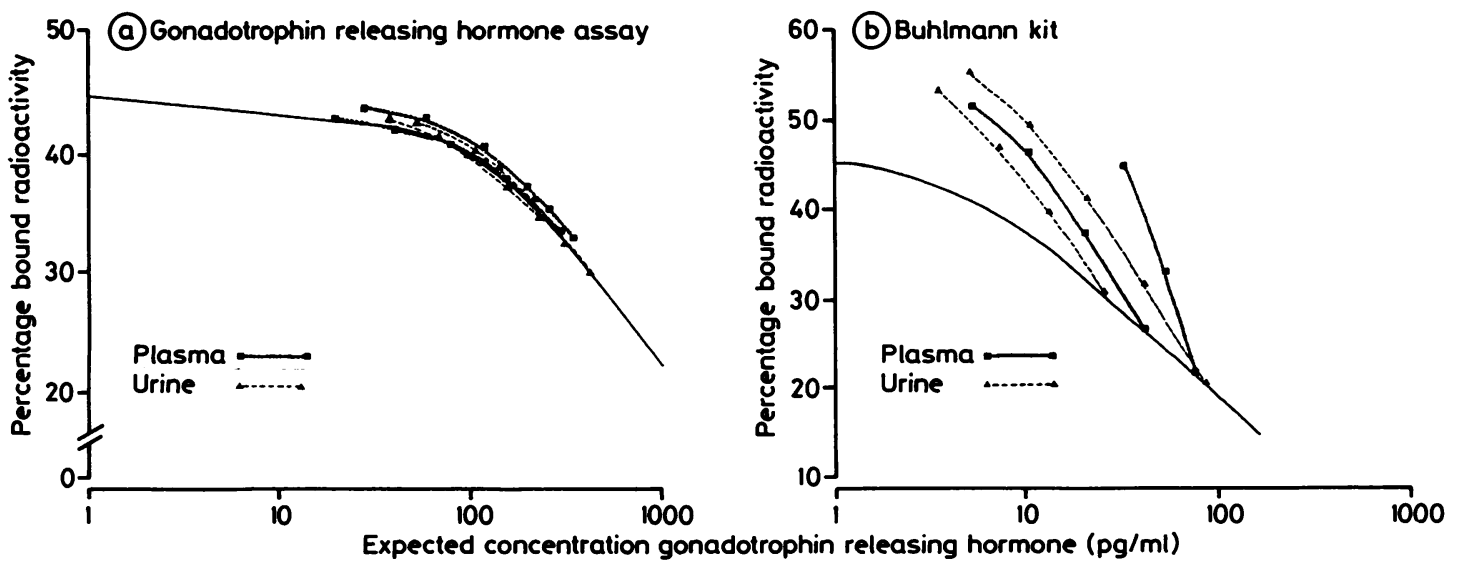

Fig 1 Parallelism of plasma and urine samples using (a) the GnRH assay and (b) the Buhlmann kit.
GnRH by the Buhlmann kit method at a GnRH concentration of $60 \mathrm{pg} / \mathrm{ml}$, and $\mathrm{Sx}$ is the standard deviation of the data set for the GnRH values obtained using the Buhlmann kit. ${ }^{12} \mathrm{~A}$ value of ${ }^{\text {Sex}} / \mathrm{Sx}$ of less than 0.2 means that the precision of the individual data points of the $x$ data set relative to the total spread of the $\mathrm{x}$ data set is good. Hence there is minimal error in using the least squares linear regression model for calculating the slope of the regression line.

There was a good correlation between both assays for plasma samples within the range of the Buhlmann kit standards. Correlation for urine samples was poor (fig 2).

\section{Profile}

Fig 3 shows a typical plasma GnRH profile from a patient who received a single subcutaneous injection of $15 \mu \mathrm{g} \mathrm{GnRH}$ (Gonadorelin, Ayerst Laboratories). Samples were analysed using the GnRH assay.

\section{Discussion}

Although several workers have developed radioimmunoassays for GnRH in plasma and urine, ${ }^{7-10}$ there are few commercially available assays and no published comparisons of assay performance. The developed GnRH assay showed good precision and recovery over a wide range of $\mathrm{GnRH}$ concentrations and parallelism. In contrast, the commercially available Buhlmann kit was unsuitable for measuring plasma GnRH in patients receiving treatment as the kit had a top standard of only $160 \mathrm{pg} / \mathrm{ml}$, well below the peak plasma concentration observed in such patients. Although precision and recovery using the Buhlmann kit were acceptable, the poor parallelism observed made it unacceptable to dilute plasma samples with high GnRH concentrations for reassay. 


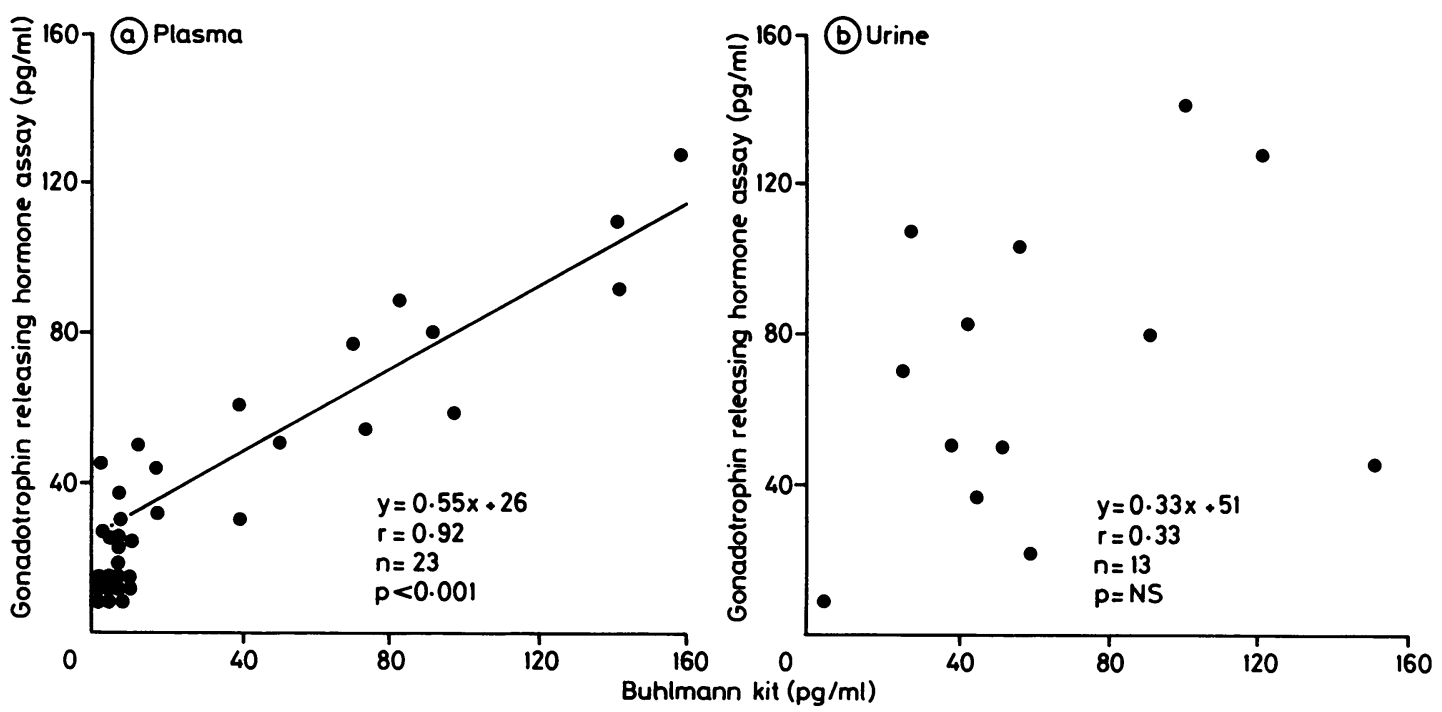

Fig 2 Correlation between the GnRH assay and the Buhlmann kit for (a) plasma samples and (b) urine samples. Results below the limit of detection for the $G n R H$ assay $(15 \mathrm{pg} / \mathrm{ml})$ were not included in the calculation of the regression coefficients.

The Buhlmann kit was considerably more sensitive than the developed GnRH assay and might, therefore, be the method of choice to detect low concentrations of GnRH. This was not in the remit of our assay development, however, and we have not addressed the potential of the assay as a diagnostic test for hypothalamic-pituitary disorders. ${ }^{13}$

Although there was a good correlation between both assays for plasma samples within the range of the

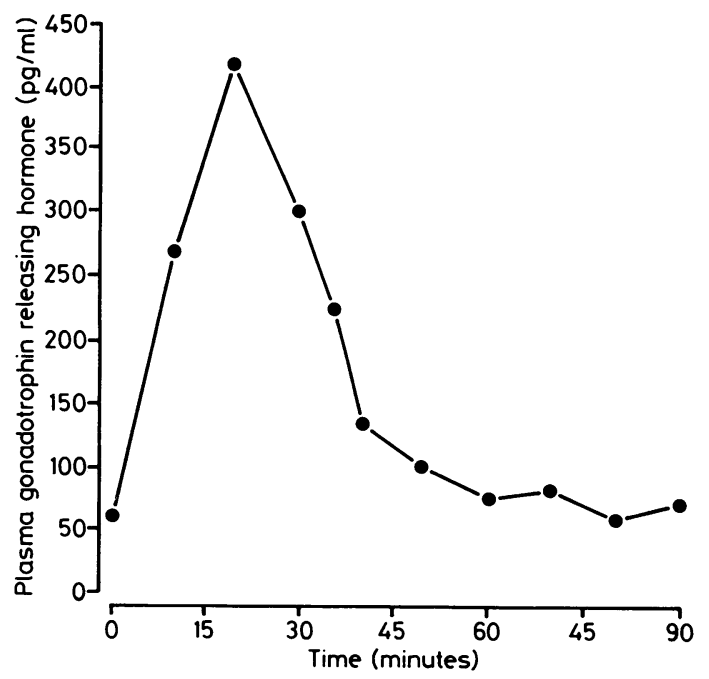

Fig 3 Plasma GnRH concentrations following a single subcutaneous injection of $15 \mu \mathrm{g}$ GnR at time 0.
Buhlmann kit standards, there was a constant positive bias which was not due to differences in the standards as both sets of standards gave identical results with either assay. The poor correlation on the urine samples and the lack of parallelism with the Buhlmann kit suggests a matrix effect with this assay.

Despite the acceptable recovery of added GnRH to plasma and urine for unextracted samples, we have occasionally observed spuriously raised GnRH concentrations, using unextracted plasma. Therefore, extraction into ethanol was chosen as the procedure to use. Extraction into ethanol gave a recovery of about $80 \%$ and evaporation under a stream of air at $70^{\circ} \mathrm{C}$ significantly reduced the time of extraction without any loss of immunoreactivity. We were unable to confirm the use of bentonite ${ }^{9}$ or florisil ${ }^{10}$ adsorption followed by acid methanol elution as a suitable method for extracting GnRH from plasma and urine. This was because we were unable to elute the GnRH from the adsorbents. Our results have shown that samples must be stored at $-20^{\circ} \mathrm{C}$ or $-70^{\circ} \mathrm{C}$ and assayed within one week of collection. The assay described is suitable for measuring GnRH in samples obtained from patients receiving treatment with GnRH.

We thank Ayerst Laboratories Ltd, Andover, England for financial support, Dr J Ginsburg, department of endocrinology, Royal Free Hospital, London for allowing us to study patients under her care, Dr P Hardiman for the collection of patient samples and Mrs J Payne for secretarial help. 


\section{References}

1 Schally AV, Arimura A, Kastin AJ, et al. Gonadotrophin-releasing hormone: one polypeptide regulates secretion of luteinising and follicle-stimulating hormones. Science 1971;173:1036-8.

2 Belchetz PE, Plant TM, Nakai Y, et al. Hypophysial responses to continuous and intermittent delivery of hypothalamic gonadotrophin releasing hormone. Science 1978;202:631-3.

3 Leyendecker G, Struve T, Plotz EJ. Induction of ovulation with chronic intermittent (pulsatile) administration of LH-RH in women with hypothalamic and hyperprolactinaemic amenorrhoea. Arch Gynecol 1980;229:177-90.

4 Meldrum DR, Chang RJ, Lu J, et al. Medical oophorectomy using a long-acting GnRH agonist-a possible new approach to the treatment of endometriosis. J Clin Endocrinol Metab 1982;54:1081-3.

5 Chang RJ, Lanfer LR, Meldrum DR, et al. Steroid secretion in polycystic ovarian disease after ovarian suppression by a longacting gonadotrophin-releasing hormone agonist. $J$ Clin Endocrinol Metab 1983;56:897-903.

6 Warner B, Worgul TJ, Drago J, et al. Effect of very high dose D$\mathrm{Leu}^{6}$-GnRH proethylamide on the hypothalamic-pituitary testicular axis in patients with prostatic cancer. $J$ Clin Invest 1983;71:1842-53.

7 Jeffcoate SL, Fraser HM, Gunn A, Holland D. Radioimmunoassay of luteinising hormone releasing factor. $J$ Endocrinol 1973;57:189-90.
8 Jeffcote SL, Fraser HM, Holland DT, Gunn A. Radioimmunoassay of luteinising hormone-releasing hormone (LH-RH) in serum from man, sheep and rat. Acta Endocrinol 1974;75: 625-35.

9 Malacora JM, Valasco E, Garcia-Vela YAG. Luteinizinghormone-releasing hormone (LRH) extraction from peripheral plasma using bentonite and its measurement by radioimmunoassay during the menstrual cycle and in menopause. Rev Invest Clin (Mex) 1980;32:11-20.

10 Bolton AE. Radioimmunoassay of Luteinising Hormone Releasing Hormone-like material in human urine. $J$ Endocrinol 1974;63:255-6.

11 Ellis GB, Desjardins C, Fraser HM. Control of pulsatile LH release in Male Rats. Neuroendocrinology 1983;37:177-83.

12 Cornbleet PJ, Gochman N. Incorrect least square regression coefficients in method comparison analysis. Clin Chem 1979;25:432-8.

13 Kawamura Y, Miyake A, Aono T, Kurachi K. Plasma luteinizing hormone-releasing hormone levels in normal women and patients with amenorrhoea. Fertil Steril 1980;34:444-7.

Requests for reprints to: Dr M L Knapp, Principal Biochemist, Westminster Hospital, Page Street, London SW1P 2AR, England. 